\title{
A Mass Balance Method for Assessing Emergy Benefit of Waste Mining for Refuse Derived Fuel Production
}

\author{
Christia Meidiana and Dwi Mashita
}

\begin{abstract}
Waste mining has been implemented in Gresik City since 2013. The aged waste is processed into refuse-derived fuel (RDF) for Cement Industry. The study objects to calculate the benefit of waste mining activity using emergy analysis. Mass balance analysis assesses total waste flow for separation, composting, and RDF production. Waste separation done by 72 scavengers in landfill contributes $1.54 \%$ waste reduction $(1.3$ ton waste) and $228.5 \mathrm{US} \$ /$ day income by selling them to middle man. Meanwhile, 265.6 ton aged waste excavated from landfill is screened, shredded and processed into 72.68 ton/day RDF type 2. By-product of this process is 184.32 ton/day residue (soil-like substances) used for land reclamation. RDF produced from landfill can substitute coal consumption in cement industry for $\mathbf{4 . 2 5}$ years. Emergy calculation comes to the result that waste treatment in landfill through scavenging, composting and waste mining contributes gross emergy benefit of $2.14 \mathrm{E}+22$ seJ/yr.
\end{abstract}

Index Terms-Landfill, refuse derived fuel, mass balance analysis, Emergy analysis.

\section{INTRODUCTION}

Waste is a by-product generated by people's consumption of agricultural and industrial substances being dissociated from natural material cycling loops as the nature cannot degrade waste for its quantity and quality because of current development pattern implemented by global society [1]-[3]. The change of the waste quality i.e. non-degradable materials and hazardous substances and the waste quantity, such as over production of waste, leads to several environmental problems. Indonesia is facing the waste problem as the waste generation growth in Indonesian cities is 2- 4\% per year, but this rate is not proportional to the level of service (LoS). Inferior financial scheme, lack of competent human resources and inadequate facilities as well as infrastructure are the main reasons for poor waste management in Indonesian cities [4]. Landfilling is the main method used for waste treatment since almost $90 \%$ waste generated is transported to the landfill. Still, many landfills are operated as an open dump site causing environmental degradation such as ground water and soil pollution and greenhouse gases (GHGs) emission. As the waste law No. 18/2008 was enacted, local government is small/middle city and large city respectively to substitute the open dump site. Furthermore, the law encourages the waste reduction through reuse, reduce, and recycle concept (3R) to

Manuscript received September 15, 2016; revised February 7, 2017.

Christia Meidiana is with the Department of Urban and Regional Planning of Faculty of Engineering, Brawijaya University, Mlg 65147 Indonesia (e-mail: c_meideiana@ub.ac.id).

Dwi Mashita was with Department of Urban and Regional Planning of Faculty of Engineering, Brawijaya University, Mlg 65147 Indonesia (e-mail dwimashita23@gmail.com). overcome the depletion of landfill space since landfills need massive land areas. Nevertheless, landfills may contain valuable resources. Significant amounts of combustible recyclable material such as plastic or paper, which is potential waste for material or energy recovery and earth construction materials, is available in waste mass [5]-[10]. Excavating the waste pile in the landfill is conducted to get the combustible material from disposal site which can be used as input for refuse derived fuel (RDF) production process as well as for energy recovery from incinerator. Other purposes of waste mining are redevelopment of landfill sites, management of landfill space, decreasing landfill area, removal of pollutant source, and reuse of recovered materials [11]-[16].

Waste mining, either for energy recovery or material recovery, has potential advantages in economic aspect if it is managed properly as presented by some previous studies attempting to calculate the profit. [17] analyzed the economic aspect of recovering foundry sands and metal fractions (iron) from landfill. [18] proposed scenarios of waste treatment in landfill through integration of resource recovery and remediation project. The results showed that for some certain conditions, it decreases the waste treatment or even is profitable. However, [19] described that the use of waste mining as source for RDF is beneficial environmentally but not economically. Other studies analyzed the environmental and economic potential of landfill mining in material recycling, energy recovery, land reclamation and pollution prevention [20]-[22]. RDF is an appropriate alternative to utilize plastic waste when recycling is not viable because of damage physical properties caused by exposure during removal process. Therefore, [23] proposed utilization of plastic waste for RDF briquette production used for fuel in small gasification system.

RDF process can reduce the environmental burden and greenhouse gases (GHGs) emission. Compare to incineration, RDF offers more benefits such as higher heating value, low moisture content, higher carbon content, and lower sulphur content [24]. The economic and environmental benefits by processing waste into other products were analyzed separately in many studies since they differ from each other. The use of emergy analysis, proposed by [25], is an attempt to enable the calculation of flows of different type of resources with different units. [26] calculated the emergy benefits of urban solid waste treatment, while [27] used emergy analysis to assess the benefits of material recycling. However, there are no studies so far aiming to assess the emergy benefits of waste mining for RDF production process. Thus, this study focuses on this assessment since some industries including cement industries in Indonesia are promoting RDF to substitute fossil fuel. 
Gresik cement industry in East Java Province started using RDF when the company ratified the cooperation with the local government to manage the waste in the landfill in 2011. Both parties are interested in waste mining in the landfill because they can take benefits from it. The cement industry can decrease the fuel expenses and the local government can reduce the waste disposal in the landfill. Therefore, this study aims to calculate the emergy benefit of waste mining in a controlled landfill for RDF production.

\section{METHODS}

\section{A. Waste Reduction}

Scavenging and composting contributes to waste reduction in the landfill. The waste reduction through scavenging is calculated based on the average separation rate done by the scavengers. The percentage is the ratio of the wet weight of the sorted waste to the total waste transported to the landfill on a daily basis. Data of waste separation was collected during 7 days observation because there is no daily recorded waste disposal. There are 72 scavengers/day working in the landfill and they are the respondents for the questionnaires comprising socio-economic questions. The average composting rate is 1.2 ton/day. Eq. 1 is used to calculate the waste reduction quantified by recovery factor of each waste type.

$$
R F_{i}[\%]=\frac{W_{i, s o r t}}{W_{i}}
$$

where $R F_{i}, W_{i}$,sort, $W_{i}$ stands for recovery factor of each waste type, separated waste wet weight type $i$, and waste wet weight type i disposed of in landfill. Calculation is conducted based on a daily basis.

\section{B. Mass Balance Analysis}

Mass balance analysis (MBA) is a method to calculate the material flowing to and out from the system. Using this method, the quantity of input to and output from waste management in landfill can be measured. Furthermore, recovery factor of recyclable material through waste treatment can be calculated enabling the prediction for future waste management in landfill. Fig. 1 describes the principles of MBA.

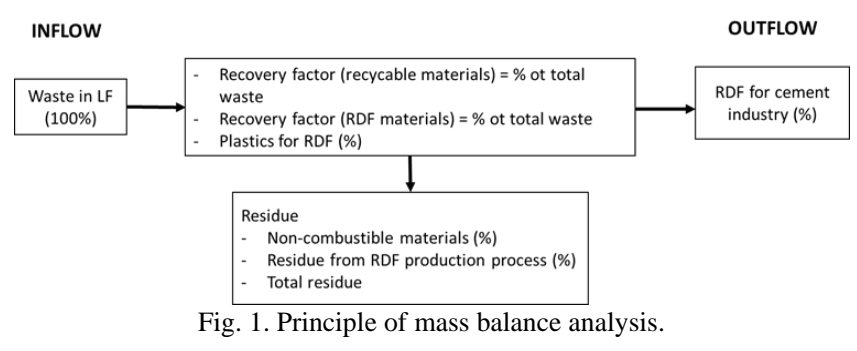

\section{Calculation of Emergy Benefit}

In this study, benefits from waste mining is calculated using emergy analysis. The analysis was introduced by [25] and it is an environmental assessment tool to evaluate the environmental performance of the system on a global scale. It counts all considered "free" environmental resources such as sunlight, wind, rain, soil, and the indirect environmental support embodied in human labour and services needed in any process occurring in the biosphere [28]. Emergy analysis comprises some steps. Initially, the system under study must be described in emergy system diagram applying some symbols. Once the system diagram is accomplished, a table comprising all types of resource involved in the system is constructed. Generally, there are four main types of input resources i.e. free renewable resources, purchased renewable resources, free non-renewable resources and purchased non-renewable resources. Purchased resources are sometimes considered as economic input. Afterwards, all raw values of the input are multiplied by their respective emergy intensity values called transformity. Transformity converts different units of the input into the same unit: solar emjoules (seJ). The results are the total emergy required for the whole process in the system. The environmental performance is evaluated by aggregating total flows for emergy indices calculation. Yet, the study focused on the gross emergy benefits and not on the evaluation of environmental performance. Fig. 2 illustrates the basic common symbols used in this study for constructing the emergy system diagram. More of the Odum symbols can be found in Odum's publication. Detailed description about emergy analysis including rules, meanings and calculation procedure can be found mainly at [25] and [28].

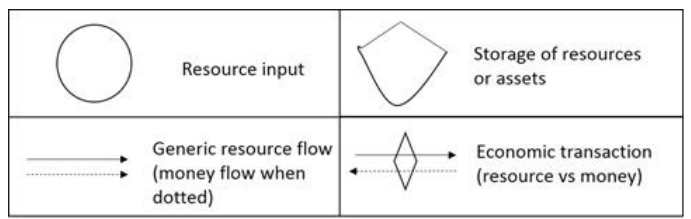

Fig. 2. Basic symbols in emergy anaylsis used in the study (adopted from [29]).

\section{Assumptions}

The following assumptions are applied to the analysis for recovery factor and emergy calculation.

1) The amount of waste disposed of daily in the landfill is the average value calculated based on the result of the 7-day-measurement of waste disposal in landfill.

2) The amount of aged waste in passive zone is calculated by measuring the volume of the passive zone. The value represents the aged waste dumped in the passive zone. Using typical aged waste density [30], the volume unit is converted to mass unit

3) Waste composition in the landfill is identical with typical waste composition in Gresik Regency.

4) Potential of waste mass utilized for RDF production process is assumed to be 257 ton/day as this value is the maximum capacity of separator and shredder.

5) Waste density is assumed to be $400 \mathrm{Kg} / \mathrm{m} 3$ and 700 $\mathrm{Kg} / \mathrm{m} 3$ for fresh waste and aged waste (mined waste) respectively [30].

6) The currency rate is $\mathrm{Rp} 13,600$ equivalent to US\$1. This value is the average value of exchange rate of Rupiah from National Central Bank in 2015

\section{RESUlT AND DisCUSSION}

The amount of waste transported to the landfill is about 257 ton/day. Organic waste is the main fraction (71.9\%), followed by plastic, paper, cardboard, metal and other 
recyclable materials amounting to $11.6 \%, 6.3 \%, 2.9 \%, 1.2 \%$ and less than $1 \%$ respectively (Fig. 3). Plastic and paper are the major recyclable materials as shown in Fig. 4. Scavengers sort mainly plastic, paper and cardboard. The separation rate by scavenger is $48 \mathrm{~kg} / \mathrm{cap} /$ day in average amounting to totally 1.3 ton waste reduction per day or $1.54 \%$ waste reduction in landfill. Based on Table I, reduction rate in the landfill through scavenging and composting is 3.95 ton/day with the total recovery factor is $1.54 \%$ indicating that scavenging and composting do not contribute significant waste reduction in the landfill. There is still a huge amount of waste disposed of to the landfill which is 252.87 ton/day. Recovery factor for organic waste, leather, rubber, and textile is zero since these items are not sorted by scavengers. The recovery factor of each material is relative low ranging between $3.7 \%$ and $9 \%$. However, scavengers take benefit from waste separation since they earn income by selling the recyclable material to the middle man picking up the sorted waste twice a week in the landfill. Totally about US\$ 228.5/day is generated from scavenging in the landfill as presented in Table II.

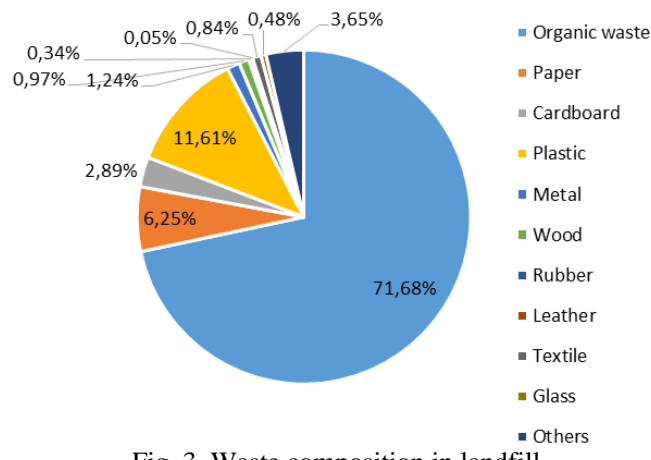

Fig. 3. Waste composition in landfill.

About 1.2 ton organic waste from street sweeping is transported to composting area inside the landfill site and sorted for composting process. It contains approximately $60 \%$ leaves and $40 \%$ stem. The recovery factor is $80 \%$ since $20 \%$ of stem is separated and treated as firewood. An overview of waste treatment process in the landfill can be seen in Fig. 5. Waste from transfer point is transported to the landfill and discharged into different waste treatment facilities in the landfill. Fresh waste is transported to disposal area in which scavengers separate manually recyclable materials. Recovery factor of the recyclable material, i.e. paper, cardboard, plastic, metals, wood, glass is $5.7 \%, 6.52 \%, 4.38 \%, 3.79 \%, 6.85 \%$, and $1.16 \%$ respectively. The recovery factor of the organic fraction from street sweeping transferred to composting facilities is $80 \%$. The residue from these process is sent to the disposal area. Meanwhile, aged waste in passive zone is excavated to be used for zero waste process including RDF production from plastic waste.

Excavated waste comprises plastic, soil-stone-coarse mixture and soil-like substances. Recovery factor for plastic is $28 \%$ (for RDF) while for soil-stone-coarse mixture and soil-like substances is $35 \%$ and $37 \%$ respectively.

This material is transported for land reclamation in the ex-lime stone mining areas in Gresik Regency. The whole mass balance analysis is depicted in Fig. 5, comprising the input from source point, the process of the waste and the output either as recycable materials, waste or RDF.

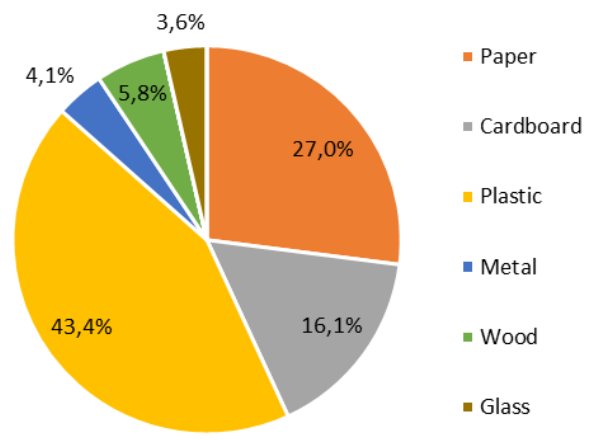

Fig. 4. Recyclable materials separated by scavengers.

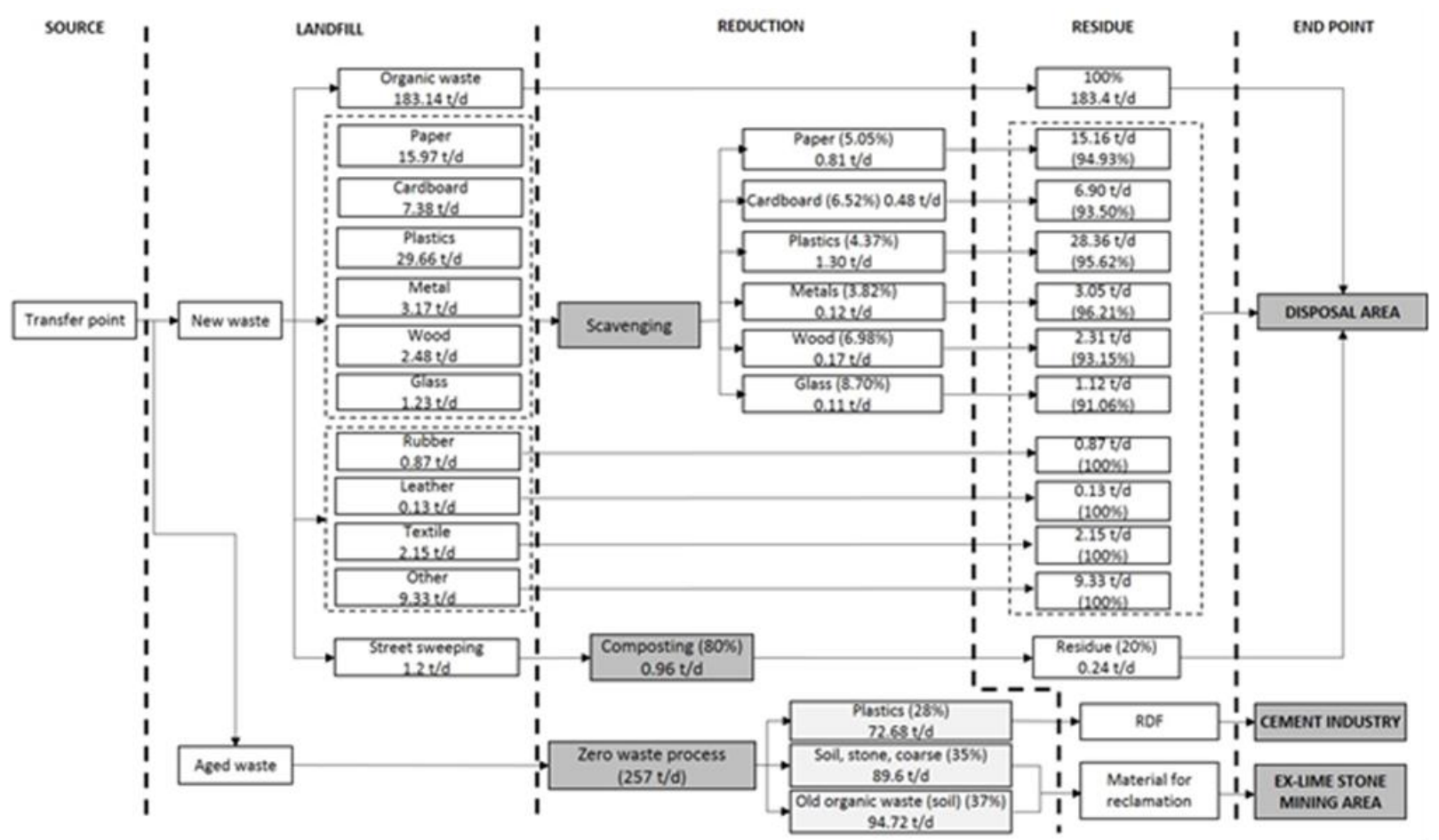

Fig. 5. Waste treatment process in the landfill. 


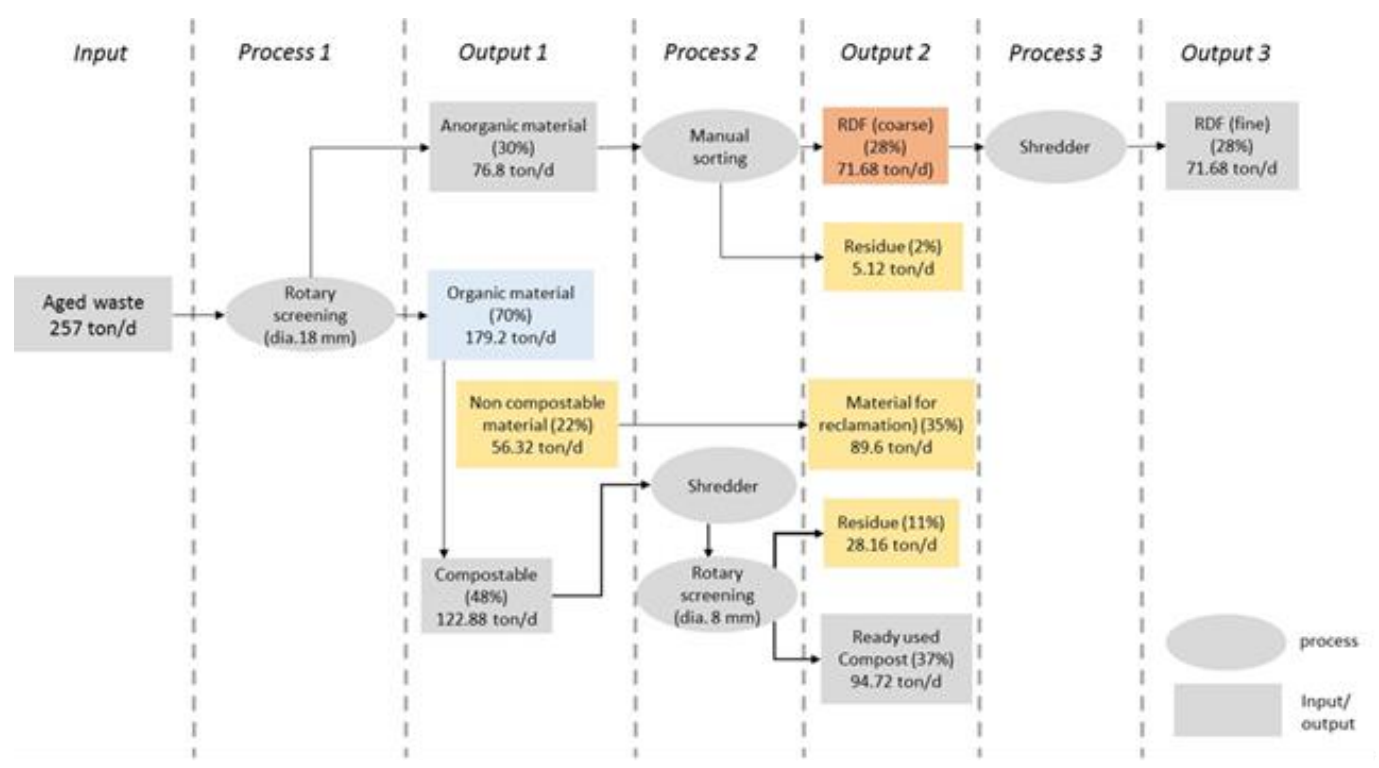

Fig. 6. RDF production process.

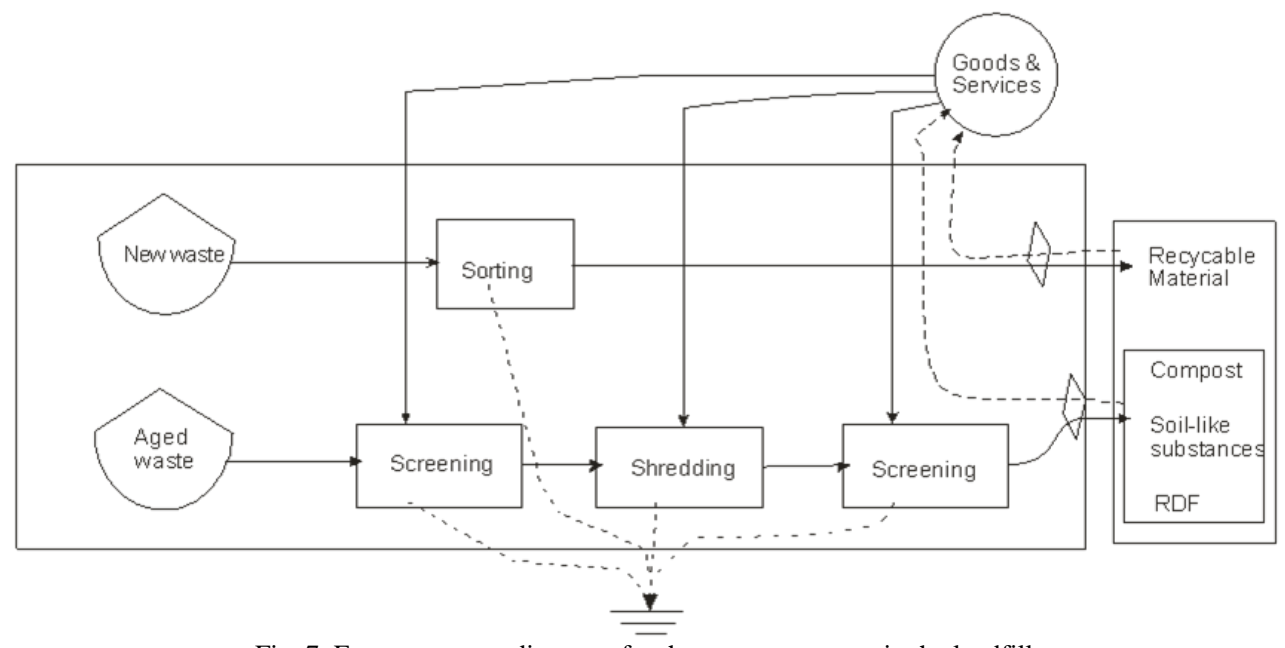

Fig. 7. Emergy system diagrams for the waste treatment in the landfill.

TABLE I: MASS BALANCE ANALYSIS IN THE LANDFILL

\begin{tabular}{|l|l|l|l|l|}
\hline Component & $\begin{array}{l}\text { Waste mass } \\
\text { (ton/d) }\end{array}$ & $\begin{array}{l}\boldsymbol{R F} \\
(\%)\end{array}$ & $\begin{array}{l}\text { Reduction } \\
\text { (ton/d) }\end{array}$ & $\begin{array}{l}\text { Residue } \\
\text { (ton/d) }\end{array}$ \\
\hline Organics & 183.21 & 0 & 0 & 183.21 \\
\hline paper & 15.98 & 5.05 & 0.81 & 15.17 \\
\hline Cardboard & 7.39 & 6.51 & 0.48 & 6.91 \\
\hline Plastic & 29.68 & 4.37 & 1.30 & 28.38 \\
\hline Metal & 3.17 & 3.82 & 0.12 & 3.05 \\
\hline Wood & 2.48 & 6.98 & 0.17 & 2.31 \\
\hline Rubber & 0.87 & 0 & 0 & 0.87 \\
\hline Leather & 0.13 & 0 & 0 & 0.13 \\
\hline Textile & 2.15 & 0 & 0 & 2.15 \\
\hline Glass & 1.23 & 8.70 & 0.11 & 1.12 \\
\hline Others & 9.33 & 0 & 0 & 9.33 \\
\hline $\begin{array}{l}\text { Street } \\
\text { sweeping }\end{array}$ & 1.2 & 80 & 0.96 & 0.24 \\
\hline Total & $\mathbf{2 5 6 . 8 2}$ & $\mathbf{1 . 5 4}$ & $\mathbf{3 . 9 5}$ & $\mathbf{2 5 2 . 8 7}$ \\
\hline
\end{tabular}

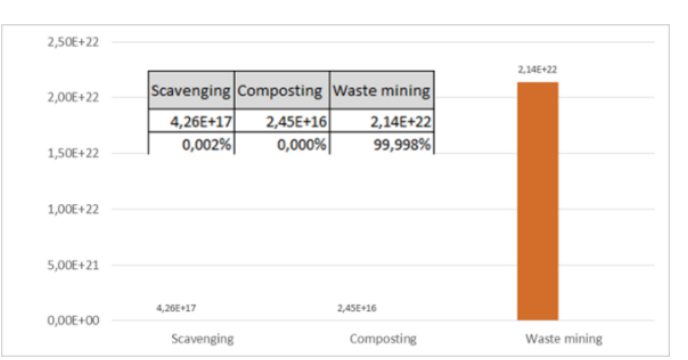

Fig. 8. Share of gross emergy benefit.
TABLE II: INCOME FROM SCAVENGING THE RECYCLABLE MATERIALS

\begin{tabular}{llrrrr}
\hline \hline No. & Product & $\begin{array}{l}\text { Price/kg } \\
(\mathrm{Rp})\end{array}$ & $\begin{array}{l}\text { Average } \\
\text { waste } \\
\text { separation } \\
(\mathrm{kg})\end{array}$ & $\begin{array}{l}\text { Income } \\
(\mathrm{Rp} / \mathrm{d})\end{array}$ & \multicolumn{1}{l}{$\begin{array}{l}\text { Income } \\
(\mathrm{US} \$ \mathrm{~d})\end{array}$} \\
\hline 1. & LDPE Plastic & 800 & 1,297 & $1,037,600$ & 76.3 \\
2. & Cardboard & 1,000 & 481 & 481,000 & 35.4 \\
3 & Glass & 400 & 107 & 42,800 & 3.1 \\
4 & Paper & 400 & 807 & 322,800 & 23.7 \\
5 & Metal/tin & 8,000 & 121 & 968,000 & 71.2 \\
6 & Wood & 500 & 173 & 86,500 & 6.4 \\
7 & Organic waste & 750 & 225 & 168,750 & 12.4 \\
\hline & & & & $3,107,450$ & 228.5 \\
\hline \hline
\end{tabular}

RDP production process involves 3 stages where each stage generates a product delivered to the next point of waste treatment. RDF is the preferred end product and soil-like substances is the by-product used for land reclamation material. Fig. 6 presents the flow chart of RDF production process. Basically, each stage aims to screen the waste based on the material type, size and use. The aged waste excavated from the landfill is transported to the first screening process to be separated based on the waste type and size. The products are inorganic and organic material where the inorganic fraction is manually sorted to separate plastic waste from other inorganic waste. It is delivered to the shredder and 
cut into small pieces with diameter of $3 \mathrm{~mm}$ generating RDF type 2. Meanwhile, the organic fraction is sorted into 2 different types i.e. compostable and non-compostable. The compostable fraction is delivered to the shredder and processed to be a fine compost ready to be used as an organic fertilizer. The remaining fraction is residue for land reclamation material.

TABLE III: THE BENEFIT OF WASTE REDUCTION THROUGH SCAVENGING, COMPOSTING AND ZERO WASTE PROCESS

\begin{tabular}{|c|c|c|c|c|c|c|c|}
\hline No. & Product & $\begin{array}{c}\text { Price/kg } \\
\text { (Rp) }\end{array}$ & $\begin{array}{l}\text { Average waste } \\
\text { separation (kg) }\end{array}$ & $\begin{array}{c}\text { Average } \\
\text { income }(\mathbf{R p} / \mathbf{d})\end{array}$ & $\begin{array}{c}\text { Average } \\
\text { income }(\mathbf{U S} \$ / \mathbf{d})\end{array}$ & $\begin{array}{c}\text { Transformity } \\
(\mathrm{se} J / \$)^{1}\end{array}$ & $\begin{array}{c}\text { Emergy Savings } \\
\text { (Benefit) seJ/y }\end{array}$ \\
\hline 1. & LDPE Plastic & 800 & 1,297 & $1,037,600$ & 76.3 & $5.40 \mathrm{E}+12$ & $1.50 \mathrm{E}+17$ \\
\hline 2. & Cardboard & 1,000 & 481 & 481,000 & 35.4 & $5.40 \mathrm{E}+12$ & $6.97 \mathrm{E}+16$ \\
\hline 3 & Glass & 400 & 107 & 42,800 & 3.1 & $5.40 \mathrm{E}+12$ & $6.20 \mathrm{E}+15$ \\
\hline 4 & Paper & 400 & 807 & 322,800 & 23.7 & $5.40 \mathrm{E}+12$ & $4.68 \mathrm{E}+16$ \\
\hline 5 & Metals/tin & 8,000 & 121 & 968,000 & 71.2 & $5.40 \mathrm{E}+12$ & $1.40 \mathrm{E}+17$ \\
\hline 7 & Organic waste & 750 & 225 & 168,750 & 12.4 & $5.40 \mathrm{E}+12$ & $2.45 \mathrm{E}+16$ \\
\hline 8 & RDF (mixed plastic) & 1,000 & 71,680 & $71,680,000$ & $5,270.6$ & $5.40 \mathrm{E}+12$ & $1.04 \mathrm{E}+19$ \\
\hline \multirow[t]{2}{*}{9} & $\begin{array}{l}\text { Material for land } \\
\text { reclamation }\end{array}$ & 800,000 & 184,320 & $1.475 \mathrm{E}+11$ & $10,842,352.9$ & $5.40 \mathrm{E}+12$ & $2.14 \mathrm{E}+22$ \\
\hline & Total & & & & & & $2.14 \mathrm{E}+22$ \\
\hline
\end{tabular}

Waste reduction through RDF production process is likely significant since there are possibilities to increase the processing capacity as showed in Fig. 6 . With the capacity of 257 ton/day, there will be 5,632 ton/month or 67,584 ton/yr waste can be processed assuming that the processor runs 22 work days per month. The source for RDF production process is totally from the landfill. During the waste mining, the fresh waste still can be deposited in other zones where waste has been excavated.

Fig. 7 describes the emergy system diagram for the waste treatment in the landfill comprising the input (goods and services) required for the process, the stages during the process and the output. The treatment involves the fresh waste and the aged waste. Labour sort new waste into different recycable materials i.e paper, plastic, metal and glass. The materials are sold to the thidr parties for input for other system such as recycling and reuse. Aged waste is excavated from the passive cell in the landfill and passes thorugh screening and shredding. The entire process involves electricity, water, labor as goods and also services. Compost, $\mathrm{RDF}$ and recyclable materials are the outputs of the process where compost is produced in composting centers and recyclable materials are sorted by scavengers. The emergy benefits of the system are represented by the symbol of economic transaction. The calculation of the emergy benefits attained from transaction of the output is conducted afterwards. The result shows that savings from fossil fuel substitution, income from selling recycable materials and compost, as well as avoidings land provision for recclamation are the positive economic transaction. Table III shows the emergy benefit of waste treatment in the landfill. Composting, scavenging and RDF production extract some quality from waste. Compost is sold to the community, the recyclable materials are sold to the middle man, RDF saves the fossil fuel expenses, and reclamation material saves the construction cost of ex-lime stone mining area rehabilitation. The total gross emergy benefit is $2.14 \mathrm{E}+22 \mathrm{seJ} / \mathrm{yr}$. The transformity of the currency is adopted from the value proposed by [31]. The share of emergy benefit is $0.002 \%, 0 \%$ and $99.998 \%$ for scavenging, composting and waste mining respectively (Fig. 8).

\section{CONCLUSION}

Based on the mass balance analysis, waste reduction potentials in the landfill through scavenging and composting reduce waste is not significant since the recovery factor through these activities is only $1.54 \%$ equals to 3.95 ton/day waste reduction. There are 252.87 ton/day waste remaining in the landfill. Waste mining for RDF production process reduces waste significantly amounting to almost $100 \%$ or 257 ton/day since the maximum capacity of the separator and shredder is about 257 ton/day. All aged waste disposed of in passive zone from year 2003 - 2013 will be entirely excavated within 4 year 3 months and 19 days with the total amount of 21,717 ton. The waste treatment in the landfill contributes benefit in the form of income of scavengers, fossil fuel saving, ex-lime stone mining area rehabilitation. Scavenging, composting, and waste mining contributes $4.26 \mathrm{E}+17 \mathrm{seJ} / \mathrm{yr}, 2.45 \mathrm{E}+16 \mathrm{seJ} / \mathrm{yr}$, and $2.14 \mathrm{E}+22 \mathrm{seJ} / \mathrm{yr}$ gross emergy benefit respectively. Waste mining generating RDF type 2 and land reclamation material is the major gross emergy benefit which is $99.99 \%$. Meanwhile, scavenging and composting has less than $1 \%$ share of gross emergy benefit. It can be concluded, that waste mining for RDF production process is a potential solution for waste problem in Indonesia since the process contains zero waste concept in which the waste is totally reduced.

\section{REFERENCES}

[1] M. E. Arias and M. T. Brown, "Feasibility of using constructed treatment wetlands for municipal wastewater treatment in the Bogota Savannah, Colombia," Ecological Engineering, vol. 35, pp. 1070-1078, 2009.

[2] D. Meadows and J. Randers, Limits to Growth: The 30-Year Update. White River, VT: Chelsea Green Publishers, 2004.

[3] C. A. S. Hall and J. W. Day, "Revisiting the limits to growth after peak oil," American Scientist, vol. 97, pp. 230-237, 2009.

[4] C. Meidiana and T. Gamse, "The new waste law: Challenging opportunity for future landfill operation in Indonesia," Waste Management, vol. 29, pp. 20-29, 2011.

[5] T. Obermeier, J. Hensel, and T. Saure, "Landfill mining: Energy recovery from combustible fractions," presented at Sixth International Landfill Symposium, Cagliari, Italy, 1997.

[6] M. Quaghebeur, B. Laenen, D. Geysen, P. Nielsen, Y. Pontikes, T Gerven, and J. Spooren, "Characterization of landfilled materials: 
Screening of the enhanced landfill mining potential," Journal of Cleaner Production, vol. 55, pp. 72-83, 2013.

[7] P. Frändegård, J. Krook, N. Svensson, and M. Eklund, "Resource an climate implications of landfill mining - a case study of Sweden," Journal of Industrial Ecology, vol. 17, pp. 742-755, 2013.

[8] W. Hogland, M. Marques, and S. Nimmermark, "Landfill mining and waste characterization: A strategy for remediation of contaminated areas," Journal of Material Cycles and Waste Management, vol. 6, pp. 119-124, 2004.

[9] J. Kurian, S. Esakku, and R. Nagendran, "Mining compost from dumpsites and bioreactor landfills," International Journal of Environmental Technology and Management, vol. 7, pp. 317-325, 2007.

[10] R. M. Hull, U. Krogmann, and P. F. Strom, "Composition and characteristics of excavated materials from a New Jersey landfill," Journal of Environmental Engineering, vol. 131, pp. 478-490, 2005.

[11] G. Rettenberger, "Results from a landfill mining demonstration project," presented at Fifth International Landfill Symposium, Cagliari, Italy, 1995.

[12] V. Zee et al., "Assessing the market opportunities of landfill mining," Waste Management, vol. 24, pp. 795-804, 2004.

[13] O. Ayalon, N. Becker, and G. Collin, "Economic aspects of the rehabilitation of the Hiriya landfill," Waste Management, vol. 26, pp. 1313-1323, 2006

[14] P. T. Jones, D. Geysen, Y. Tielemans, S. V. Passel, Y. Pontikes, B. Blanpain, M. Quaghebeur, and N. Hoekstra, "Enhanced landfill mining in view of multiple resource recovery: A critical review," Journal of Cleaner Production, vol. 55, pp. 45-55, 2013.

[15] T. Prechthai, M. Padmasri, and C. Visvanathan, "Quality assessment of mined MSW from an open dumpsite from recycling potential," Resource Conservation and Recycling, vol. 53, pp. 70-78, 2008.

[16] R. Raga and R. Cossu, "Landfill aeration in the framework of a reclamation project in Northern Italy," Waste Management, vol. 34, pp. 683-691, 2014.

[17] M. Zanetti and A. Godio, "Recovery of foundry sands and iron fractions from an industrial waste landfill," Resource Conservation and Recycling, vol. 48, pp. 396-411, 2006.

[18] P. Frändegård, J. Krook, and N. Svensson, "Integrating remediation and resource recovery: On the economic conditions of landfill mining," Waste Management, vol. 42, pp. 137-147, 2015.

[19] M. Danthurebandara, S. V. Passel, I. Vanderreydt, and K. V. Acker, "Assessment of environmental and economic feasibility of enhanced landfill mining," Waste Management, vol. 45, pp. 434 - 447, 2015.

[20] C. Zhou, W. Fang, W. Xu, A. Cao, and R. Wang, "Characteristics and the recovery potential of plastic waste obtained from landfill mining," Journal of Cleaner Production, vol. 80, pp. 80-86, 2014.

[21] A. Winterstetter, D. Laner, H. Rechberger, and J. Fellner, "Framework for the evaluation of anthropogenic resources: A landfill mining case study - Resource or reserve?" Resource Conservation and Recycling, vol. 96, pp. 19-30, 2015.

[22] C. Zhou, Z. Gong, J. Hu, A. Cao, and H. Liang, "A cost-benefit analysis of landfill mining and material recycling in China," Waste Management, vol. 35, pp. 191-198, 2015.
[23] C. Chiemchaisri, B. Charnok, and C. Visvanathan, "Recovery of plastic wastes from dumpsite as refuse derived fuel and its utilization in small gasification system," Bioresource Techn., vol. 101, pp. $1522-1527,2010$

[24] Y. H. Chang, W. C. Chen, and N. B. Chang, "Comparative evaluation of RDF and MSW incineration," Journal of Hazardous Materials, vol. 58, pp. 33-45, 1998.

[25] H. T. Odum, Environmental Accounting: Emergy and Environmental Decision Making, John Wiley and Sons, New York, NY, 1996.

[26] F. Agostinho et al., "Urban solid waste plant treatment in Brazil: Is there a net emergy yield on the recovered materials?" Resources, Conservation and Recycling, vol. 73, pp. 143-155, 2013.

[27] B. Lacarrière et al., "Emergy assessment of the benefits of closed-loop recycling accounting for material losses," Ecological Modelling, vol. 315, pp. 77-87, 2015 .

[28] M. T. Brown and S. Ulgiati, "Energy quality, emergy, and transformity: H. T. Odum's contributions to quantifying and understanding systems," Ecological Modelling, vol. 178, pp. 201-13, 2004

[29] S. Ulgiati, S. Bargigli, and M. Raugei, "An emergy evaluation of complexity, information and technology, towards maximum power and zero emissions," Journal of Cleaner Production, vol. 15, pp. 1359-1372, 2007

[30] United National for Environmental Program (2005), Solid Waste Management (Volume II: Regional Overviews and Information Sources), CalRecovery, Inc. California, USA.

[31] University of Florida. (2008). National Environmental Accounting Database. Indonesia. [Online]. Available: http://www.cep.ees.ufl.edu/nead/data.php?country=69\&year=409

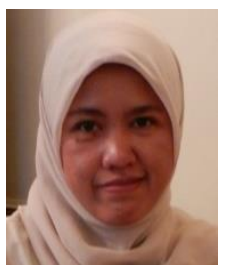

Christia Meidiana was born in May, 1972 in Semarang, Indonesia. She has been an associate professor in the Department of Urban and Regional Planning, Faculty of Engineering, Brawijaya University, Malang, Indonesia. She received her masterr's degree in renewable energy from Fachhochschule Koeln, Germany in 2004 and Dr.techn degree in environmental technology from Technische Universitaet Graz, Austria in 2012 .

She has been invloving in some projects and research projects related to environmental field such as biogas management, waste management, green house emission and renewable energy development. She is now the Head of the Master Program for Urban and Regional Planning at the Faculty of Engineering, Brawijaya University. Her main research theme was "The Emergy Analysis for Municipal Solid Waste Management". She wrote also a book chapter in "Waste Management - An Integrated Vision in 2012 Currently, she is working on rural biogas project in East Java, Indonesia.

Dr. Meidiana is a member of Asia-Pacific Chemical, Biological \& Environmental Engineering Society (APCBEES). 